\title{
Joining the New Band: Factors Triggering the Intentions of Malaysian College and University Students to Adopt 4G Broadband
}

\author{
*Wong Lai Soon, Neerjang Lama, Bobby Chai Boon Hui, Wong Kee Luen \\ Universiti Tunku Abdul Rahman, Malaysia \\ *lswong@utar.edu.my
}

\begin{abstract}
The constantly intensifying demand for mobility has generated enormous market opportunities for telecom companies. The Internet has transformed lives of the Homo sapiens over the last decade in manners beyond the horizons of imaginations. 4G; the new kid on the block is the abbreviation for fourth-generation wireless; the phase of mobile communications providing high quality connections for transportable devices. By drawing on the attributes of the Technology Acceptance Model (TAM) which is an established methodology in technology based product acceptance researches; this paper contemplates the factors that influence the intentions of Malaysian college and university students to adopt 4G broadband for academic and for pleasure purposes. A theoretical framework has been proposed for this study which consisting of four independent variables, namely Perceived Ease of Use, Perceived Usefulness, Subjective Normand Perceived Enjoyment. The dependent variable of this study is Intention to Use.
\end{abstract}

Keywords: Customer Attitude, Internet, Product diffusion, TAM, Technology

\section{Introduction}

The immensity and attractiveness of mobile devices fastened with the progression of speedy mobile networks has made it feasible to amplify the convolution of mobile applications and services. Interactions and services in the course of telecommunication networks that edge with mobile devices are becoming progressively more admired on a global magnitude and have galvanized the tech-customer relationship to a newer and higher level (Oscar, 2008; June et al., 2005). 4G is an expression employed to illustrate the next elevation of advancement in the field of mobile communications (MCs) and it is also referred to as International Mobile Telecommunications. The 4G system proposes to resolve the existing inconveniences of the $3 \mathrm{G}$ systems and to make available an extensive selection of innovative services that are communed wirelessly(Noureddine, Mohammad and Faouzi, 2008; Samuel, 2012). The proliferation of online information resources have resulted in college students reduced their effort in retrieving information from campus library (Lubans, 1998 \&1999; Pew Research Center, 2002; Shackleford, Thompson, \& James, 1999) (as cited in Metzgera, Flanagina, \& Zwarunb, 2003). And the trend of using World Wide Web to retrieve information is rising and is rising fast (Chen, 2008). Students are evolving to be behaviorally different from other generations, Prensky (2001) named this generation as "digital natives" who have been brought and wrapped up in the media of the digital age from video games to cell phones to internet. This student way of life which insists on the intense usage of telecommunication is now awakening several internet service providers to target this emerging and exceedingly profitable target group (Gary, 2005; Lucy \& David. 2005; Marcelline \& Subhash, 2005).

With the fast phase development of educational sector in Malaysia; University and college students have increased tremendously and remodeled to become one of the key consumer market segments, as firstly, this group has satisfying purchasing power, with conveniently available educational loans. Secondly, their potential earnings are also higher than many other segments of the population (Sabri et al.,2008). With the internet penetration rate in Malaysia on a steady and high rise (65\% expected in 2012 according to the Malaysian Communications and Multimedia Commission - MCMC) and with the saturation of the 3G market, consumers now seeks for a higher level of technology advancement and offerings to reduce its dampened gusto caused with low speeds and also to remove traces of the technological monotony as placed by earlier editions of internet services. As a result, it becomes imperative to have a methodical and comprehensive study on selected variables that add to the technology acceptance and contribute to a higher level of economic growth. 


\section{Literature Review}

The $4^{\text {th }}$ generation or the commonly termed $4 \mathrm{G}$ internet is a vital improvement in escalating the service features of online activities. The study by George \& Thomas, (2005), established that online competence endows economic intensification. A number of researchers recommended that the $4 \mathrm{G}$ operators must spread out the core application from data increment to incorporate mobile accessibility enrichment (Lu \& Lu, 2006). 4G communication networks without a glitch endeavors to assimilate existing heterogeneous wireless communication technologies to facilitate the provision of high-speed communication.

\section{Review of Relevant Theoretical Models}

Figure 1: Relevant Theoretical Model 1: Original Technology Acceptance Model (TAM)

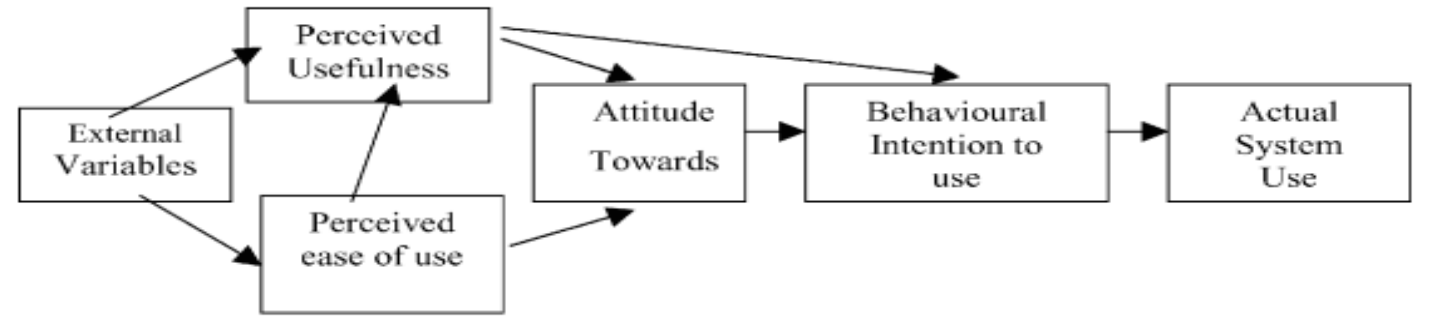

(Davis, Bagozzi \& Warshaw, 1989)

In particular, to forecast the recognition and approval of contemporary technologies, researchers have comprehensively engaged the technology acceptance model (TAM) (Davis, 1986), which adapted from the theory of reasoned action (TRA) by Ajzen and Fishbein, (1980) and Fishbein and Ajzen, (1975). In general, the technology acceptance model (TAM) by Fred Davis, (1989) scrutinizes the interceding function of perceived ease of use and perceived usefulness on the likelihood of system use (Legris et al., 2003). Perceived usefulness is identified as the prospective user's subjective probability that making use of a particular application system will boost his or her job performance within an organizational perspective (Ulun \& Nuray, 2012). According to Davis et al., (1989) perceived ease of use designates the degree to which the potential user expects the intended structure to be discharged of any effort. TAM is instituted to endow an evenhanded representation of a user's intention to make use of technology (Legris et al., 2003).

Figure 2: Relevant Theoretical Models 2

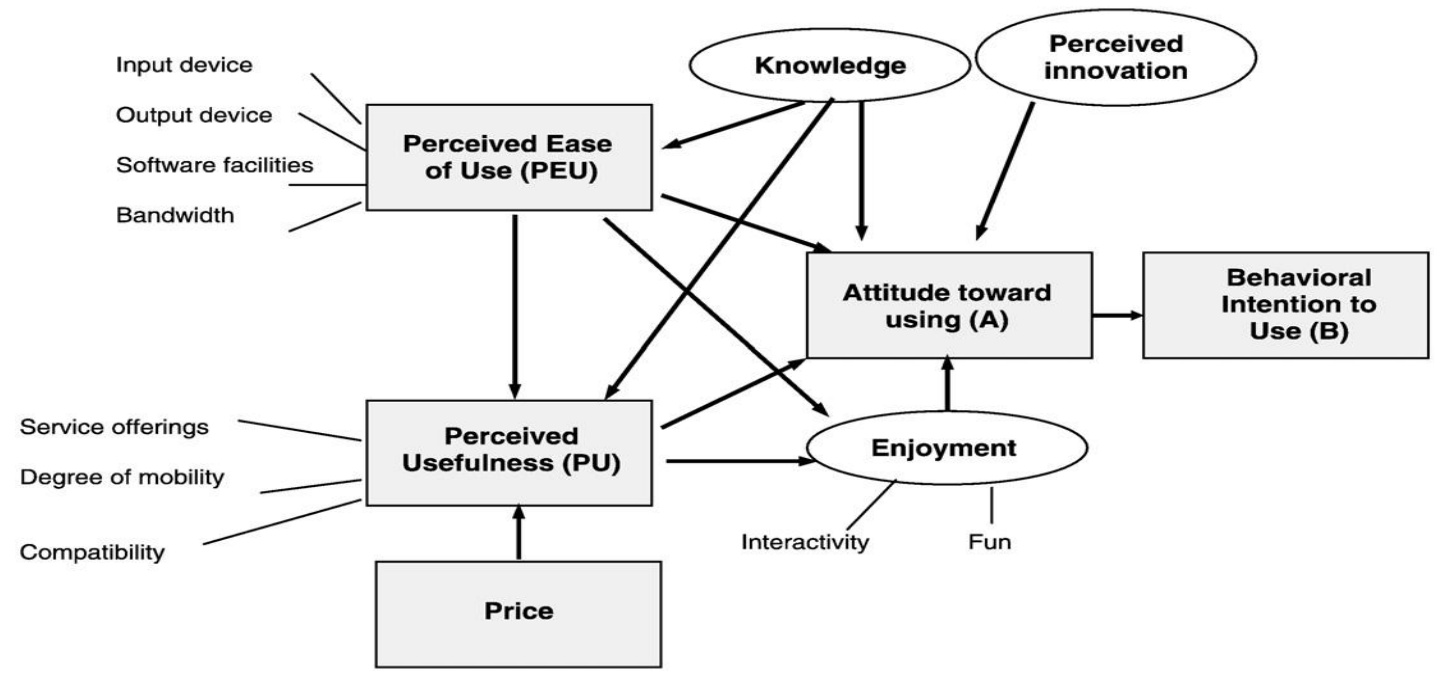

Adopted from: Pagani \& Fine, (2008), Value network dynamics in 3G-4G wireless communications: A systems thinking approach to strategic value assessment. Journal of Business Research, 61, 1102-1112. 
The model developed by Pagani \& Fine, (2008) focuses on the causal relationships among Perceived Ease of Use (PEU), Perceived Usefulness (PU), and Price on Behavioral Intention to Use. A quantitative exploratory study was done in Italy in year 2004 on 1000 mobile users. Data were collected using telephone survey. There are 2 independent variables; Perceived Ease of Use, and Perceived Usefulness. Behavioral Intention to Use is the dependent variable and attitude toward using is the mediating variable in this study. From the result of the research, Perceived Ease of Use and Perceived usefulness were found positively effecting Behavioral Intention to Use.

\section{Figure 3: Relevant Theoretical Models 3}

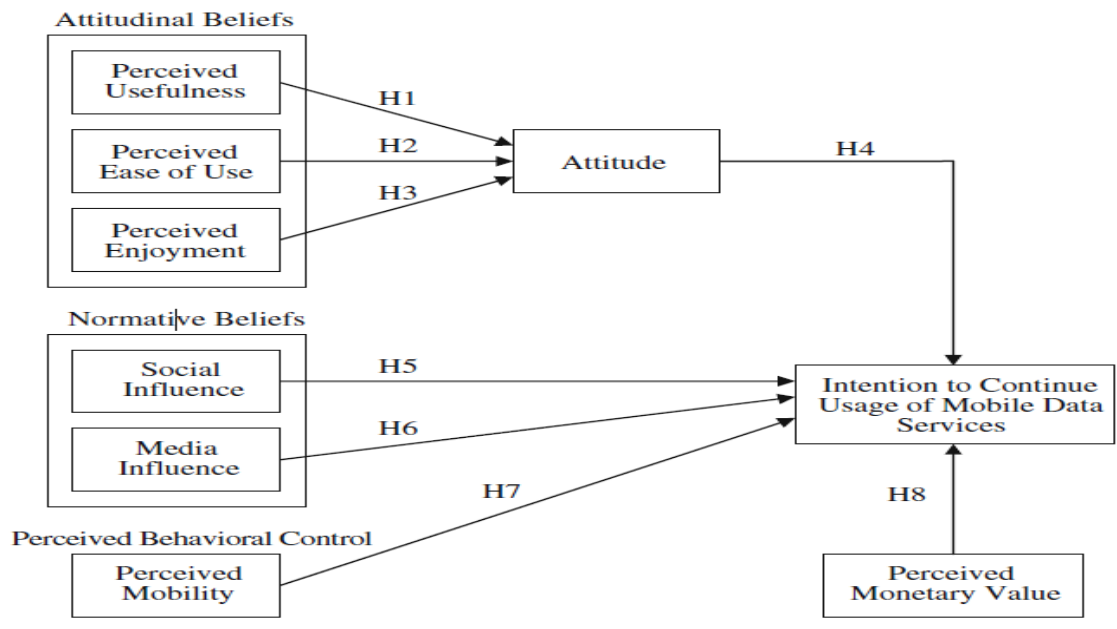

Adopted from: Hong, Thong, Moon \& Tam (2008). Understanding the behavior of mobile data services consumers.

In the above model Intention to continue using mobile data services is the dependent variable, while attitudinal beliefs, normative beliefs, perceived monetary value, and perceived behavioral control are the independent variables. In this research, the variable of attitude is mediating independent and dependent variables. Result of study indicates that attitudinal beliefs, normative beliefs, perceived monetary value, and perceived behavioral control have significant positive effect on intention to continue using the mobile data services.

\section{Figure 4: Relevant Theoretical Model4}

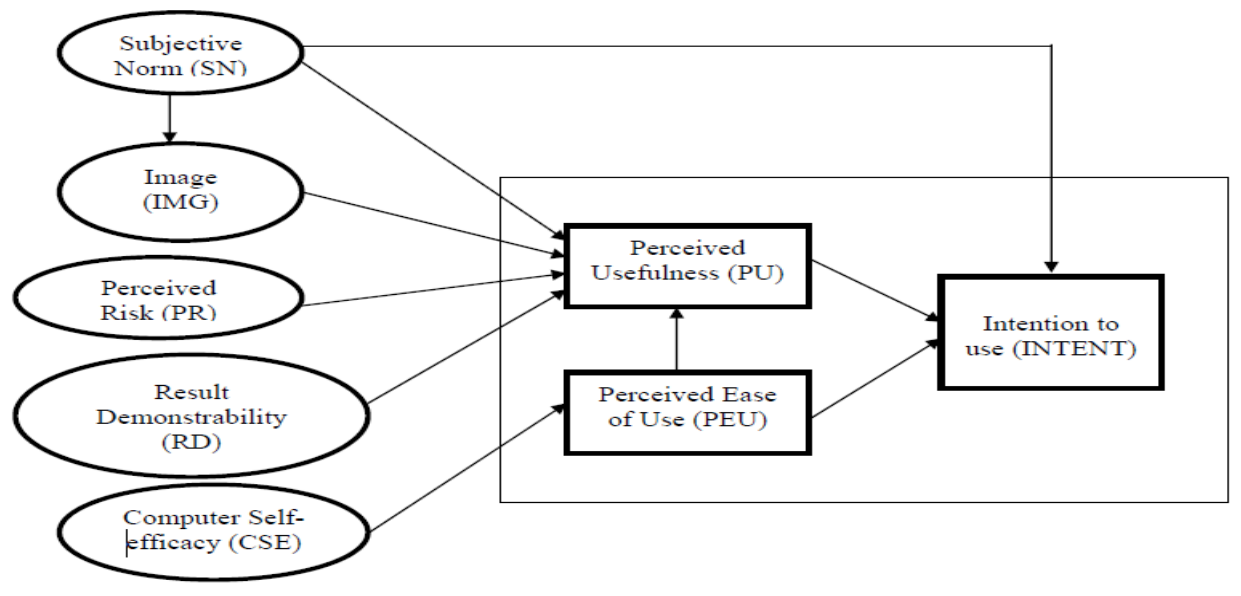

Figure 4. Research Framework

Adopted from: Ramayah, Chin, Norazah \& Amlus, (2005). Determinants of Intention to Use an Online Bill Payment System among MBA Students. E-Business, (9), 80-91. 
The research outline is based on the extended Technology Acceptance Model (TAM2). Researchers investigated students' intention to make use of online bill payment system. In total, 120 part time MBA students were surveyed. The results disclosed that perceived ease of use and perceived usefulness are the important drivers of intention to use the online bill payment system. Subjective norm, image, result demonstrability and perceived as of use are also established to be the main genesis of perceived usefulness while perceived risk was found to have a negative relationship.

\section{Proposed Theoretical / Conceptual Framework}

Figure 5: Extended TAM model for 4G adoption

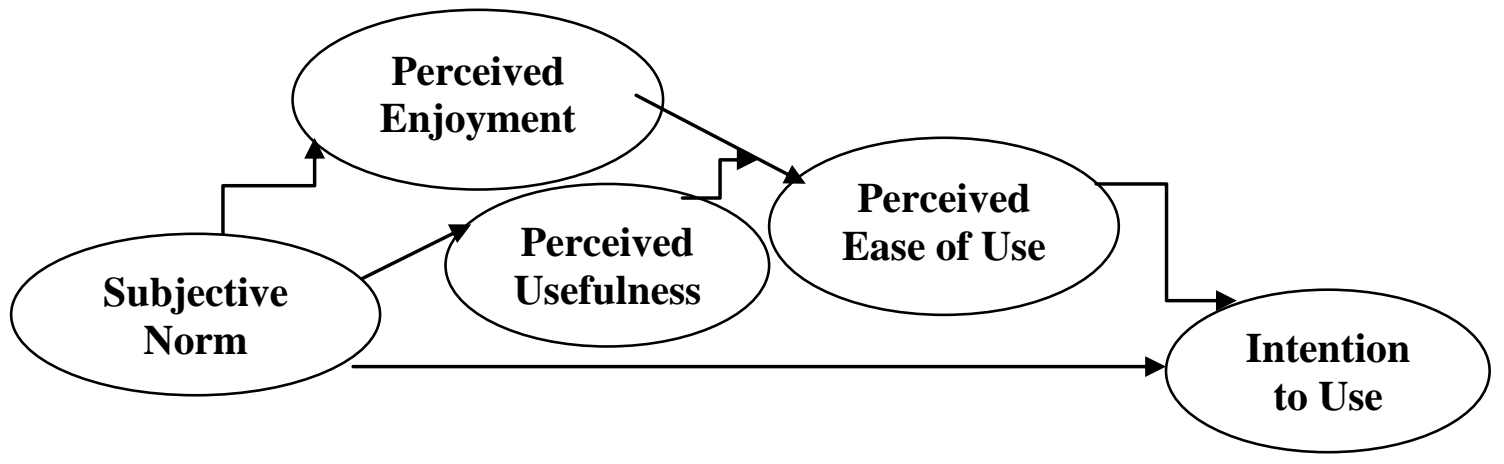

Based on the literature review, this research paper proposes the above illustrated conceptual model for the purpose of understanding the factors triggering the intentions of Malaysian college and university students to adopt 4G. The model illustrated above portrays the conceptual framework to serve as foundation to examine the relationship among the variables. Subjective norm is the only independent construct in this study whereas perceived ease of use, perceived usefulness, and perceived enjoyment mediating the relationship between subjective norm and the dependent construct of intention to use.

\section{Discussion of Variables}

Intention to Use: Behavioral intention refers to the strength of individual intention on usage and performing behavior which is based on a cognitive appraisal of how the behavior improves one's performance (Liao \& Lichtensteiny, 2006).There is a well-reported linkage between behavioral intention and actual usage stage. According to Mohamed \& Nizar, (2010), in the original TAM model "usefulness" is to a large degree predicted by "ease of use"; both of them clarify "intention to use" and "actual use" through "attitude toward use". In spite of its accomplishment, one of the negative aspects of the TAM is that it does not capture the effect of consumers' emotion on their attitude toward using new product and finally their actual behavior (Bagozzi\& Yi, 1988). Undeniably, consumer behavior theory offers confirmations that utilitarian motives are not adequate to clarify consumer behavior toward a product (Childers et al., 2001).

Perceived Usefulness: TAM postulates that, perceived usefulness (PU) and perceived ease of use are two elemental parts for envisaging user acceptance, and that the outcome of external variables on intention are found to be mediated by these two key beliefs (Adams et al., 1992; Davis, 1989; Davis et al., 1989; Mathieson, 1991). PU is characterized as an individual's perception that bringing into play an innovative technology will improve or perk up her/his performance (Davis, 1989, 1993).PE is frequently engaged as an independent variable in a model (technology acceptance model) or theory (theory of planned behavior) in several studies of recognition (Ong and Lai, 2006; Timothy Teo, 2011). Venkatesh and Davis (2000) instituted that perceived usefulness holds an optimistic effect on students' intention to utilize online learning. Drennan et al. (2005) established that, among the reasons that inferred students' toward online learning, perceived use fullness is the strongest amongst all the variables. In TAM, behavioral intention is influenced by both PU and Attitude. These relationships have been studied and supported by several studies (Adams et al., 1992; Davis, 1989; Hu et al., 1999; Venkatesh and Davis, 1996, 2000). 
Perceived Ease of Use: According toDavis et al., (1989) perceived ease of use designates the degree of potential user expectation on the intended structure to bed is charged of any effort. It has been established that perceived ease of use positively affects perceived usefulness and contributes to behavior (Davis, 1989; Szajna, 1996; Venkatesh, 2000; Venkatesh, and Davis, 2000). Perceived ease of use in general is considered as an element connected with computer-based information systems as they can pilot individuals to experience pleasure or annoyance depending on usability (Davis, 1989). Consumers of technology-based self-service may be apprehensive about the exertion necessary to utilize such preferences and the involvedness of the course of service delivery (Dabholkar, 1996). Existing studies reveal that perceived ease of use considerably influences consumer acceptance of electronic commerce (Liao and Cheung, 2001). Similarly, a study by Clarke (2001) on the dynamics impinging on the utilization of wireless handheld devices in England also shored up this position. He established that ease of use is one of the top five impact factors determining use of wireless handheld devices. Similarly perceived ease of use found to has a positive effect on attitude (Huang, Lin, \& Chuang, 2007).

Subjective Norm: Subjective norm reveals the effect of noteworthiness and outlook of other people on a user's conduct. The theory of reasoned action (TRA) and theory of planned behavior (TPB) argue that subjective norm influences behavioral intention (Fishbein and Ajzen, 1975; Ajzen, 1991).Subjective norm, which is actually an offshoot of normative beliefs that demonstrates the sensitivity of social pressures, positioned on the perceiver by individuals or groups who are important to the perceiver, whether to or not to act upon such an act (Gianluigi et al., 2011). The underlying principle for a straight consequence of subjective norm on behavior intention is that individuals may perhaps desire to perform a behavior even if they are not satisfactorily disposed to that behavior if they consider that one or more of their key referents support that behavior (Liao \& Lichtensteiny, 2006).Understanding on how social norms are at variance may perhaps in addition lend a hand to concentrate on perplexing findings that subjective norm is often of no consequence and is the weakest among the three predictors of TPB's(Conner and Armitage, 1998). Subjective norm is also instituted to impinge on users' intention to make online purchase (Pavlou and Fygenson, 2006), play online games (Hsu and Lu, 2004), adopt blog (Hsu and Lin, 2008), and use advanced mobile services (Lopez-Nicolas et al., 2008). Li et al. (2008) publicized that subjective norm considerably influences user trust on many organizational information systems.

Perceived Enjoyment: Perceived enjoyment (PE) is a form of a fundamental psychological motivation (Davis et al., 1989).PE refers to the extent user perception on the enjoyment of using the ICT in its own preciseness apart from the instrumental benefits derived from using the technology (i.e. perceived usefulness). In TAM, perceived usefulness, perceived ease of use (Davis, 1989), and perceived enjoyment (Davis et al., 1992) are found to determine user behavior intentions. These symbolize the utilitarian and hedonic facets of consumer experience. Davis et al. (1992) proposed the idea of perceived enjoyment that transpires in the natural performance of an activity. Studies have also revealed that ICT acceptance can be influenced by intrinsic factors (i.e. perceived enjoyment), even when the technology is utilized at the place of work (Heijden, 2004). Further the considerable effect of perceived enjoyment on instant messaging usage advocates the value of enjoyment and gratification in technology adoption (Heijden, 2004). A study by Chen et al. (2008) reveals that the three dynamics: perceived enjoyment, ease of use and social interaction amplified users' intention to make use of e-mail and Misperceived usefulness and perceived ease of use is capable to be influential in realizing prized results, while perceived enjoyment can transpire from the usage of technology itself without any other incentive.

\section{Implication of the Study}

In addition to the established utility founded TAM variables, one additional factor; Perceived Enjoyment and the interrelationship between these variables are considered as essential constructs for elucidating the 4G adoption behavior. The value of this model should be tested by empirical study in future research. The study can be applied as a point of strong reference for additional investigation on the importance, as well as the influences of $4 \mathrm{G}$ adoption. It can also serve as a preliminary model to analyze customer preferences on technology over time. This study can prove useful for academician, researchers, and students to acquire deeper and meaningful insights into the perception customers hold about superior technology. The presented conceptual aspects intend to offer a different perspective in understanding the multiplicity and variances of 
customer preferences in the adoption of a new technology based product. The factors impinging on the diffusion of a product can also be comprehended from this study.

The study can be employed to aid internet providers in emphasizing areas that need attention and are of critical importance to the acceptance and adoption of $4 \mathrm{G}$ service provided to university students in Malaysia. The paper is relevant and valuable for practitioners in understanding the major issues facing customer preferences for internet services in the present day. Service providers ought to focus on reinforcing relative advantage and entertaining attributes to promote the adoption of 4G.

\section{References}

Adams, D. A., Nelson, R. R. \& Todd, P. A. (1992). Perceived usefulness, ease of use, and usage of information technology: a replication. MIS Quarterly, 16(2), 227-47.

Ajzen, I. (1991). The theory of planned behavior. Organizational Behaviour and Human Decision Processes $50(2), 179-211$.

Ajzen, I., Fishbein, M. (1980). Understanding attitudes and predicting social behavior. Englewood Cliffs, NJ; Prentice-Hall.

Bagozzi, R. P. \& Yi, Y. (1988). On the evaluation of structural equation models. Journal of the Academy of Marketing Science, 16(1), 74-94.

Chen, L. G. (2008). The presence and usage of computer technology and the internet in the classroom: An examination of secondary school students' and teachers' attitudes. The Claremont Graduate University, 2008. 3294590. ProQuest Dissertations and Theses.

Childers, T. L., Carr, C. L., Peck, J. \& Carson, S. (2001). Hedonic and utilitarian motivations for online retail shopping behavior. Journal of Retailing, 77(4), 511-35.

Clarke, R. (2001). Person-location and person-tracking: Technologies, risks and policy implications. Information Technology and People Summer, 3, 206-231.

Conner, M. \& Armitage, C. J. (1998).Extending the theory of planned behavior: a review and avenues for future research. Journal of Applied Social Psychology, 28(15), 1429-64.

Dabholdar, P. A. (1996). Consumer Evaluations of New Technology-based Self-service Options: An Investigation of Alternative Models of Service Quality. International Journal of Research in Marketing, 13(1), 29-51.

Davis, F. D. (1989). Perceived usefulness, perceived ease of use, and user acceptance of information technology. MIS Quarterly, 13(3), 319-40.

Davis, F. D. (1993). User acceptance of information technology: system characteristics, user perceptions and behavioral impacts. International Journal of Man-Machine Studies, 38(3), 475-87.

Davis, F. D., Bogazzi, R. P. \& Warshaw, P. R. (1989). User acceptance of computer technology: a comparison of two theoretical models. Management Science, 35(8), 982-1003.

Davis, F. D., Bagozzi, R. P. \& Warshaw, P. R. (1992). Extrinsic and intrinsic motivation to use computers in the workplace. Journal of Applied Social Psychology, 22, 1111-1132.

Drennan, J., Kennedy, J. \& Pisarski, A. (2005). Factors affecting student attitudes toward flexible online learning in management education. The Journal of Educational Research, 98(6), 331-8.

Fishbein, M. \& Ajzen, I. (1975). Belief, Attitude, Intention and Behavior: An Introduction to Theory and Research, Addison-Wesley, Reading, MA.

Gary, D. M. (2005). Student use of the Internet. Journal of Educational. Technology Systems, 33(1), 53-66.

George, S. F. \& Thomas, M. K. (2005.). Broadband and Economic Development: A Municipal Case Study from Florida.

Gianluigi, G., Alberto, M. \& Alessandro, M. P. (2011). Nature and antecedents of a marketing approach according to Italian SME entrepreneurs: A structural equation modeling approach. International Journal of Entrepreneurial Behaviour \& Research, 17(4), 342 - 360.

Hans-van-der, H. (2004). User Acceptance of Hedonic Information Systems.MIS Quarterly, 28(4), 695-704.

Hong, S. J., Thong, J. Y. L., Moon, J. Y. \& Tam, K. Y. (2008). Understanding the behavior of mobile data services consumers, 431-445.

Hsu, C. L. \& Lin, J. C. C. (2008). Acceptance of blog usage: the roles of technology acceptance, social influence and knowledge-sharing motivation. Information and Management, 45(1), 65-74.

Hsu, C. L. \& Lu, H. P. (2004). Why do people play online games? An extended TAM with social influences and flow experience. Information and Management, 41, 853-68. 
Huang, J. H., Lin, Y. R. \& Chuang, S. T. (2007). Elucidating user behavior of mobile learning: A perspective of the extended Technology Acceptance Model. Electronic Library, 45(6), 387-393.

Hu, L. \& Bentler, P. M. (1999). Cutoff criteria for fit indexes in covariance structure analysis: conventional criteria versus new alternatives. Structural Equation Modeling, 6(1), 1-55.

June, L., James, E. Y. \& Chun-Sheng, Y. (2005). Personal innovativeness, social influences and adoption of wireless Internet services via mobile technology. The Journal of Strategic Information Systems, 14(3), 245-268.

Legris, P., Ingham, J. \& Collerette, P. (2003). Why do people use information technology? A critical review of the technology acceptance model. Information \& Management, 40(2), 191-204.

Liao, Z. \& Cheung, M. T. (2001). Internet-based e-Shopping and Consumer Attitudes: An Empirical Study. Information and Management, 38(5), 299-306.

Liao, Z. \& Lichtensteiny, S. (2006). Consumer Acceptance of Third Generation Mobile Value-added Services: A Survey of Hong Kong Consumer Perceptions.

Li, X., Hess, T. J. \& Valacich, J. S. (2008). Why do we trust new technology? A study of initial trust formation with organizational information systems. The Journal of Strategic Information Systems, 17(1), 39-71.

Lopez-Nicolas, C., Molina-Castillo, F. J. \& Bouwman, H. (2008). An assessment of advanced mobile services acceptance: contributions from TAM and diffusion theory models. Information and Management, 45(6), 359-64.

Lubans, J. (1998). How first-year university students use and regard Internet resources. Available from Duke University Libraries Web site: www.lib.duke.edu/staff/orgnztn/lubans/docs/1styear/firstyear.htm

Lubans, J. (1999). Students and the Internet. Available from Duke University Libraries Web site: www.lib.duke.edu/staff/orgnztn/lubans/docs/study3.htm.

Lucy, F. \& David, M. (2005). Broadband: benefits and problems. Telecommunications Policy, 29(2-3), 223-236.

Lu, W. W. \& Lu, P. D. P. W. (2006). Open Wireless Architecture (OWA) Open Wireless Architecture (OWA)Defining China's Fourth Defining China's Fourth Defining China's Fourth Generation Mobile Communications Generation Mobile Communications.

Marcelline, F. \& Subhash, D. (2005). An exploration of student internet use in India: the technology acceptance model and the theory of planned behavior. Campus-Wide Information Systems, 22(4), 233 - 246.

Mathieson, K. (1991). Predicting user intentions: comparing the technology acceptance model with the theory of planned behavior. Information Systems Research, 2(3), 173-91.

Metzgera, M. J., Flanagina, A. J. \& Zwarunb, L. (2003). College student Web use, perceptions of information credibility, and verification behavior. Computers \& Education, 41, 271-290.

Mohamed, S. \& Chtourou, N. S. (2010). Rethinking the TAM model: time to consider fun. Journal of Consumer Marketing, 27(4), $336-344$.

Noureddine, B., Mohammad, S. \& Obaidat, F. Z. (2008). Intelligent network functionalities in wireless 4G networks: Integration scheme and simulation analysis. Computer Communications, 31(16), 37523759.

Ong, C. H. \& Lai, J. Y. (2006). Gender differences in perceptions and relationships among dominants of elearning acceptance. Computers in Human Behavior, 22(5), 816-29.

Oscar, P. (2008). A Social Cognitive Perspective on Mobile Communication Technology Use and Adoption. Social Science Computer Review, 27(1), 76-95.

Pagani, M. \& Fine, C. H. (2008). Value network dynamics in 3G-4G wireless communications: A systems thinking approach to strategic value assessment. Journal of Business Research, 61, 1102-1112.

Pavlou, P. A. \& Fygenson, M. (2006). Understanding and predicting electronic commerce adoption: an extension of the theory of planned behavior. MIS Quarterly, 30(1), 115-43.

Pew Research Center. (15 September, 2002).The Internet goes to college: how students are living in the future with today's technology. Available: www.pewinternet.org/reports/pdfs/PIP_College_Report.pdf

Prensky, M. (2001). Digital Natives Digital Immigrants. 9.

Ramayah, T., Chin, Y. L., Norazah, M. S. \& Amlus, I. (2005).Determinants of Intention to Use an Online Bill Payment System among MBA Students. E-Business, 9, 80-91.

Sabri, M. F., MacDonald, M., Masud, J., Paim, L., Hira, T. K. \& Othman, M. A. (2008). Financial Behavior and Problems among College Students in Malaysia: Research and Education Implication. Consumer Interests Annual, 54(2). 
Samuel, Y. (2012). Mobile applications and 4G wireless networks: a framework for analysis. Campus-Wide Information Systems, 29(2).

Shackleford, J., Thompson, D. S. \& James, M. B. (1999). Teaching strategy and assignment design: assessing the quality and validity of information via the Web. Social Science Computer Review, 17(2), 196-208.

Szajna, B. (1996) Empirical Evaluation of the Revised Technology Acceptance Model, Management Science, 42, 85-92.

Timothy, T. (2011). Modeling the determinants of pre-service teachers' perceived usefulness of e-learning. Campus-Wide Information Systems, 28(2), 124 - 140.

Ulun, A. \& Nuray, T. (2012). Marketing Intelligence \& Planning, 30(4), 444-459.

Venkatesh, V. \& Davis, F. D. (1996). A model of the antecedents of perceived ease of use: development and test. Decision Sciences, 27(3), 451-81.

Venkatesh, V. \& Davis, F. D. (2000). A theoretical extension of the technology acceptance model: four longitudinal field studies. Management Science, 46(2), 184-204. 